\title{
A Microarray Analysis of Rice Near-Isogenic Lines that Cover QTLs Associated with Callus Proliferation
}

\author{
Fumio TAGUCHI-SHIOBARA ${ }^{1 *}$, Junshi YAZAKI ${ }^{2}$, Masahiro ISHIKAWA ${ }^{2}$, \\ Fumiko FUJII $^{2}$, Kanako SHIMBO ${ }^{3}$, Zempei SHIMATANI ${ }^{3}$, Yuko NAGATA ${ }^{3}$, \\ Akiko HASHIMOTO $^{3}$, ${\text { Tomoya } \text { OHTA }^{2} \text {, Yuki SATO }}^{2}$, Sachiko HONDA ${ }^{3}$, \\ Kimiko YAMAMOTO ${ }^{4}$, Katsumi SAKATA ${ }^{3}$, Takuji SASAKI ${ }^{4}$, \\ Naoki KISHIMOTO ${ }^{2}$ and Shoshi KIKUCHI ${ }^{2}$ \\ ${ }^{1}$ Biochemistry Department, National Institute of Agrobiological Sciences \\ (Tsukuba, Ibaraki 305-8602, Japan) \\ ${ }^{2}$ Molecular Genetics Department, National Institute of Agrobiological Sciences \\ (Tsukuba, Ibaraki 305-8602, Japan) \\ ${ }^{3}$ Institute Research Division I, Institute of Society for Techno-Innovation of Agriculture, Forestry, and \\ Fisheries (Tsukuba, Ibaraki 305-0854, Japan) \\ ${ }^{4}$ Genome Research Department, National Institute of Agrobiological Sciences \\ (Tsukuba, Ibaraki 305-8602, Japan)
}

\begin{abstract}
Near-isogenic lines (NILs) were applied for the first time to microarray analysis of 8,987 randomly selected expressed sequence tags (ESTs) aiming at screening rice genes associated with seed callus proliferation. Callus proliferation of the variety Koshihikari is poor, since its callus tends to become brown with time. We developed ten NILs that each had a chromosomal segment of the variety Kasalath on chromosome 1 in a Koshihikari background, to cover a region that contains two QTLs for subcultured callus color, $q S c 1-1$ and $q S c 1-2$. The existence of QTLs was verified through tissue culture of the seed calli of these NILs. mRNAs from the calli of three NILs that had the Kasalath allele in $q S c 1-1$ and/or $q S c 1-2$ were applied to microarray analysis. A comparison of expression profiles between Koshihikari and each NIL followed by Northern hybridization showed that 22 unique genes were induced and 15 unique genes were repressed in the calli of these Kasalath allele-containing NILs on chromosome 1. The results of a cis-element search using $500 \mathrm{bp}$ of genomic sequence upstream of each gene suggested that the expression profiles of GA- and/or sugar-responsive genes were different between each NIL and Koshihikari, and that defense-related genes and genes that act negatively in metabolism were repressed in the NILs compared with Koshihikari.
\end{abstract}

Discipline: Biotechnology

Additional key words: cDNA microarray, NILs, Oryza sativa L., seed callus

\section{Introduction}

The rice seed callus derived from the scutellum of the mature embryo is most often used in the production of transgenic plants by the Agrobacterium-mediated transformation method. To produce transgenic plants efficiently, the seed callus must proliferate sufficiently and must be competent for somatic embryogenesis or regeneration. Koshihikari, a leading rice variety in Japan, has little callus proliferation ability, since its callus tends to become brown with time. To overcome this problem, media for Koshihikari cells have been improved by decreasing the nitrogen source $e^{4,5,13}$.

Plant callus proliferation is a quantitative trait, and genes conferring callus maintenance and regeneration have been reported in several species ${ }^{2,11,12}$. In rice, quantitative trait loci (QTLs) that affect the proliferation of seed callus were identified ${ }^{16}$. Up to now, no QTL for callus proliferation has been cloned. Many genes expressed in regeneration have been reported, such as housekeeping genes, hormone-responsive genes, genes involved in signal transduction, homeotic genes, genes coding for extracellular proteins, and maturation genes ${ }^{3}$. However, it is 

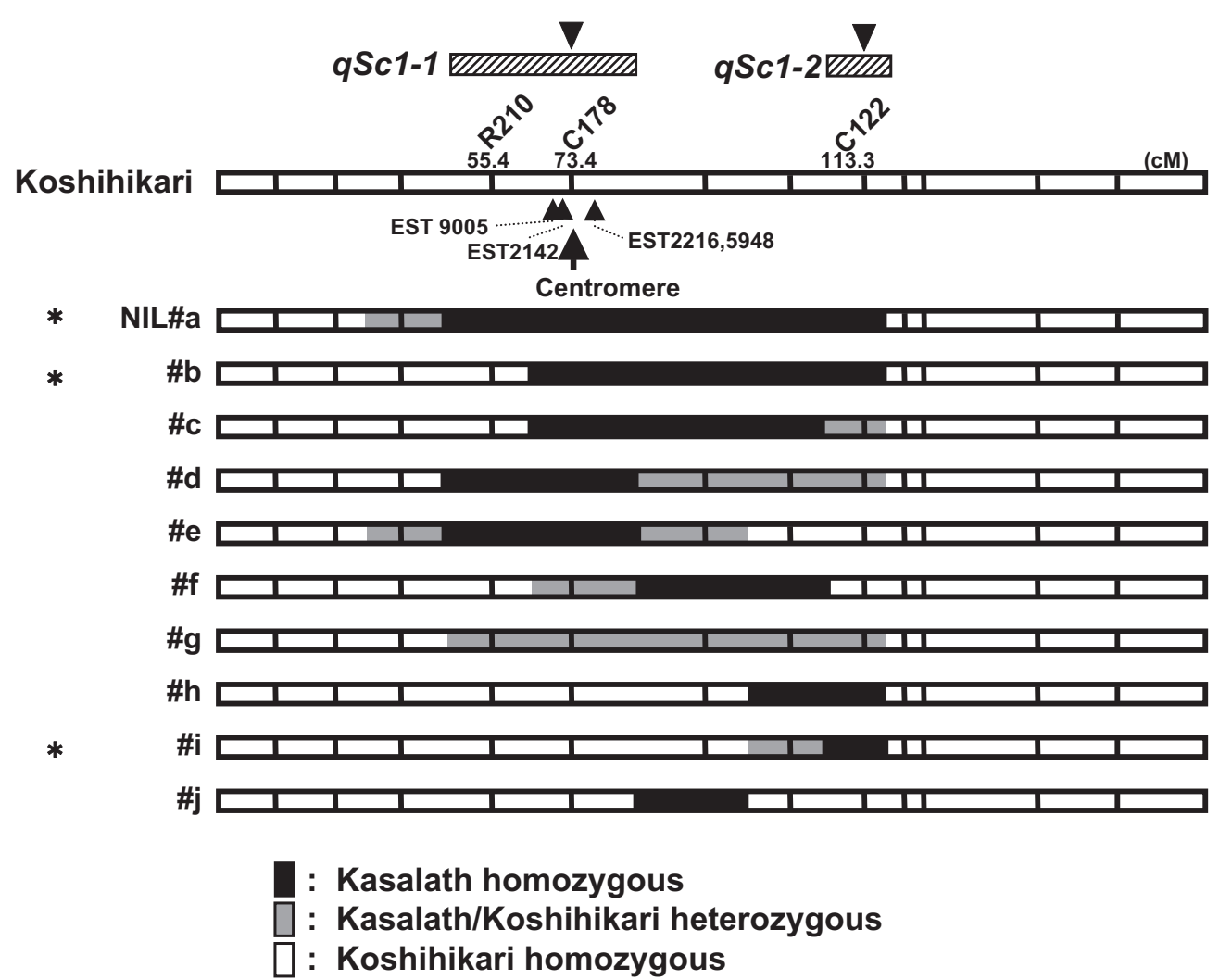

Fig. 1. Graphical genotypes of chromosome 1 of Koshihikari and ten near-isogenic lines (NILs) from \#a to \#j revealed by 14 RFLP markers

*: NILs applied to a microarray analysis. Locations of QTLs are shown on the upper side of Koshihikari. The RFLP markers significant at the $0.1 \%$ level are named. Arrows indicate the most significant marker in each QTL detected in single-point analysis of variance. Genetic distance is described according to 'The Latest High-Density Rice Genetic Map, Including 3267 Markers’ (http://rgp.dna.affrc.go.jp/publicdata/geneticmap2000/index.html).

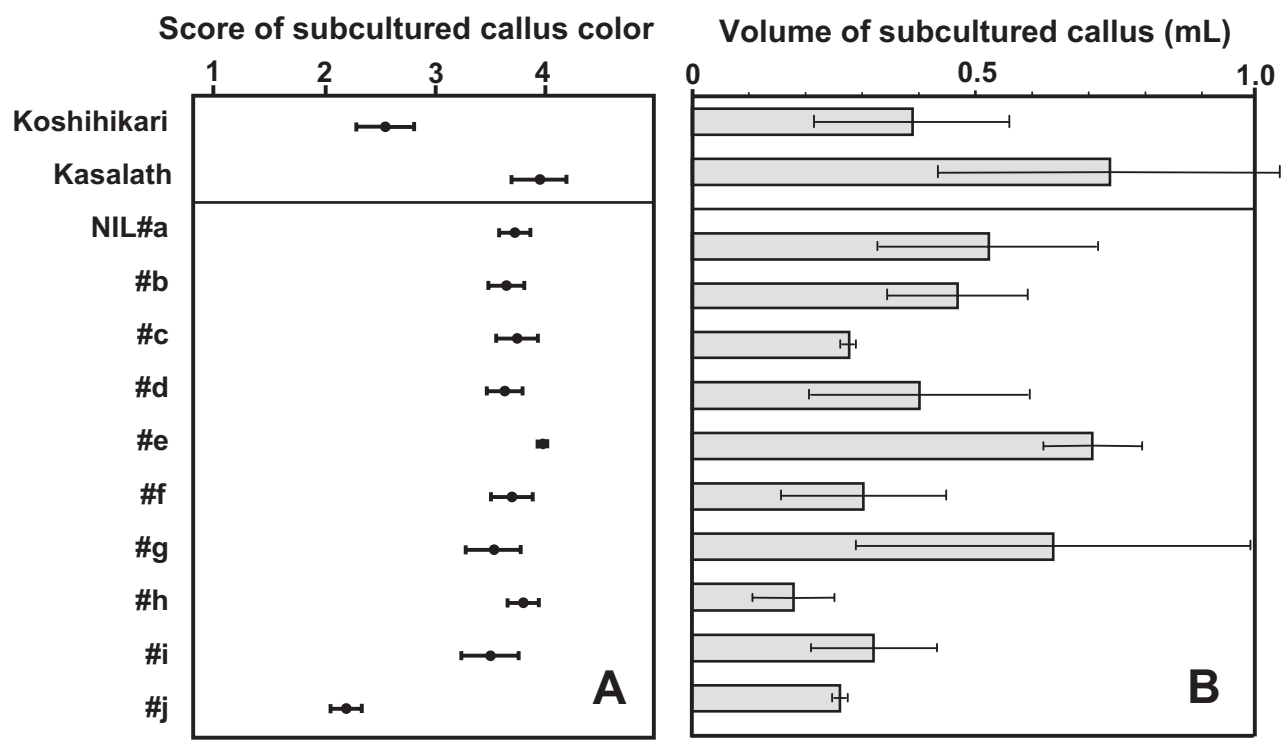

Fig. 2. Callus proliferation abilities of ten NILs and their parents, Koshihikari and Kasalath, after subculture for 1 week in a N6 medium supplemented with $30 \mathrm{~g} / \mathrm{L}$ sucrose, $0.3 \mathrm{~g} / \mathrm{L}$ casein acid hydrolysate, $1.15 \mathrm{~g} / \mathrm{L}$ proline and $1 \mathrm{mg} / \mathrm{L}$ of 2, 4-D About $80 \mathrm{mg}$ of calli was used to initiate subculture. $\mathrm{n}=7$. The mean $\pm \mathrm{SE}$ was used to represent Koshihikari, Kasalath, and each NIL. A: Colors of subcultured calli. Color scores: 1, brown; 2, brownish-yellow; 3, yellow; 4, yellowish-white. B: Volume of subcultured calli. 
not clear what causes the differences in callus proliferation among different varieties.

To compare the expression profiles of rice lines with different callus proliferation abilities, we developed ten NILs in which the allele of an indica variety, Kasalath, was introduced in the region of two QTLs controlling subcultured callus color, $q S c 1-1$ and $q S c 1-2$, in the Koshihikari background. The existence of two QTLs was demonstrated through the evaluation of callus proliferation of Koshihikari and these NILs. Koshihikari and three NILs that had greater callus proliferation than Koshihikari were applied to microarray analysis. To screen the genes induced or repressed by the Kasalath allele in the region of the QTLs, the expression profiles in subcultured calli were compared with Koshihikari and each NIL.

\section{Materials and methods}

\section{Plant material and culture procedures}

A $\mathrm{BC}_{1} \mathrm{~F}_{3}$ population, derived from a cross between Koshihikari and Kasalath ${ }^{17}$, was used to develop the NILs. Out of $187 \mathrm{BC}_{1} \mathrm{~F}_{3}$ plants, two plants were selected since they had Kasalath allele in $q S c 1-1$ and/or $q S c 1-2$, and were backcrossed twice with Koshihikari to obtain $20 \mathrm{BC}_{3} \mathrm{~F}_{1}$ plants. Ten $\mathrm{BC}_{3} \mathrm{~F}_{2}$ plants were screened using 52 RFLP markers dispersed throughout the genome. These plants were verified to have a Koshihikari allele in at most 2 markers in all chromosomes except for chromosome 1. Selfed seeds derived from ten $\mathrm{BC}_{3} \mathrm{~F}_{2}$ NIL plants and mature seeds of Koshihikari and Kasalath were cultured. The procedures from callus induction to regeneration of the shoots have been described previously ${ }^{16}$.

\section{Microarray analysis, Northern hybridization, gene annotation, and cis-element search}

Koshihikari and three NILs-NIL\#a, NIL\#b, and NIL\#i-were used to prepare total RNAs. Calli after 1 week's subculture in liquid callus-inducing medium were used to isolate total RNA and were applied to the microarray analysis as described previously ${ }^{1}$. On glass microarray slides, 8,987 randomly selected ESTs were spotted in duplicate ${ }^{18}$. ArrayGauge (FujiFilm, Tokyo) was used for image analysis. When the fluorescence intensity ratio of each NIL to Koshihikari changed by more than threefold, the gene was judged to be induced or repressed. Northern hybridization procedures were performed as previously described ${ }^{1}$, and $10 \mu \mathrm{g}$ of total RNA was used.

To annotate genes, the GenBank database and the rice full-length cDNA database, KOME (http:// cdna01.dna.affrc.go.jp/cDNA/), were searched for the sequences of the ESTs, using the BLAST program to find mRNA sequences. Pfam (http://pfam.wustl.edu/) was used to predict protein domains. Using the PLACE ciselement database ${ }^{6}$ (http://www.dna.affrc.go.jp/PLACE/), $500 \mathrm{bp}$ of the genomic sequence upstream from the initiation codon of each mRNA or the 5' terminus of each fulllength cDNA clone was searched for cis-elements.

\section{Results and discussion}

\section{Development of NILs and tissue culture of their seed calli}

Ten NILs were selected to have the Kasalath allele in the region containing two QTLs for callus color, $q S c 1$ 1 and $q S c 1-2$, in the Koshihikari background (Fig. 1).

Sometimes QTLs detected in primary QTL analysis are not detected in the NILs. In this study, the existence of QTLs having a sufficient effect was confirmed through tissue culture of ten NILs that had the Kasalath allele in the region containing $q S c 1-1$ and/or $q S c 1-2$ in the Koshihikari background. Nine NILs, from NIL\#a to \#i, showed better callus color in subculture (Fig. 2A). Seven NILs, from NIL\#a to \#g, increased the fresh weight of regenerated calli including the shoots, roots, and differentiated structures (Fig. 3). This suggests that a Kasalath allele in the region including $q S c 1-1$ would improve sub-

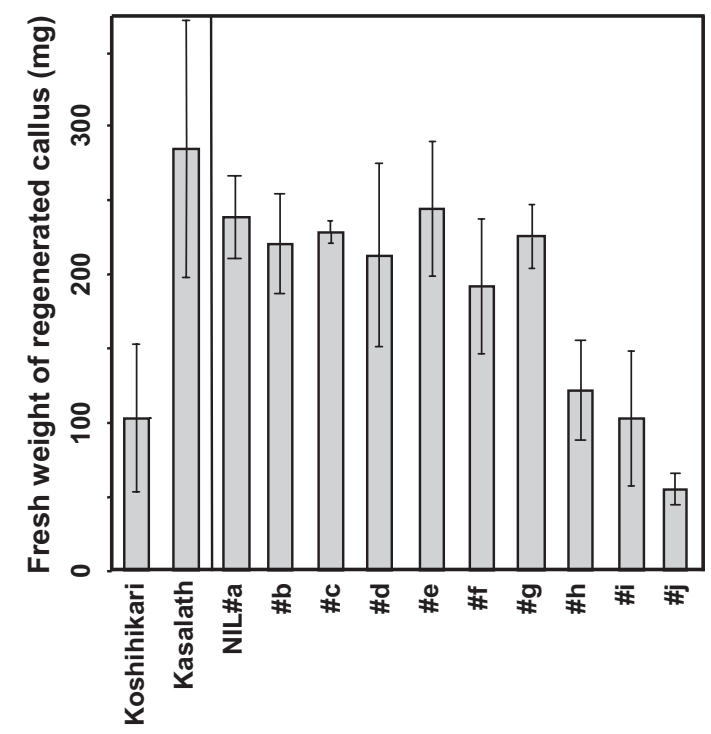

Fig. 3. Regenerated callus proliferation of ten NILs and their parents, Koshihikari and Kasalath, after regeneration for 4 weeks in medium containing kinetin and NAA

The average fresh weight of calli, including the shoots, roots, and differentiated structures, were calculated for each dish. The mean $\pm \mathrm{SE}$ for each of the 5 dishes containing 10 calli was used to represent Koshihikari, Kasalath, and each NIL. 
cultured callus color and increase the fresh weight of regenerated calli, regardless of whether the Kasalath allele is heterozygous or homozygous. This region contains ferredoxin-nitrite reductase gene and it was recently clarified to be a regeneration QTL ${ }^{10}$. In Koshihikari, nitrite reductase activity is lower than other varieties, and toxic nitrite ion $\left(\mathrm{NO}_{2}^{-}\right)$, which is not reduced, accumulates in cultured cells and causes browning of the callus followed by restrained cell growth ${ }^{13}$. Considering these facts, $q S c 1-1$ might be the ferredoxin-nitrite reductase gene.

On the other hand, a Kasalath allele in the region including $q S c 1-2$ improved subcultured callus color (Fig. 2A), however, it did not increase the fresh weight of regenerated calli (Fig. 3). Callus proliferation of NIL\#j was the same as that of Koshihikari (Figs. 2 \& 3), which implies the region that is covered by NIL\#j does not include $q S c 1-1$ nor $q S c 1-2$ (Fig. 1).

\section{Identification of genes induced or repressed in NILs}

In microarray analysis, 44 unique genes were screened to show different profiles between Koshihikari and each NIL (Tables $1 \&$ 2). Of these 44 genes, 37 were induced or repressed by a Kasalath allele in the region of QTL. To verify this result, 25 of the 44 genes were subjected to Northern hybridization, and 15 of them (15/25; $60 \%$ ) were confirmed. Since the genotype of QTL did not explain the expression patterns of most genes (Tables $1 \& 2$ ), these genes are considered to act somewhere in the downstream of these QTLs in the gene regulation cas-

Table 1. List of 22 unique genes induced in at least one NIL after subculture in medium containing 2,4-D

\begin{tabular}{|c|c|c|c|c|c|c|c|c|c|c|c|}
\hline \multirow[t]{2}{*}{$\begin{array}{l}\text { EST } \\
\text { clones }\end{array}$} & \multirow[t]{2}{*}{ Chr } & \multirow[t]{2}{*}{$\begin{array}{l}\text { PAC or } \\
\text { BAC clone }\end{array}$} & \multirow[t]{2}{*}{ Gene identification } & \multirow[t]{2}{*}{$\begin{array}{l}\text { Full-length } \\
\text { cDNA }\end{array}$} & \multicolumn{3}{|c|}{$\begin{array}{l}\text { Microarray analysis } \\
\text { Induced ratio }\end{array}$} & \multicolumn{4}{|c|}{$\begin{array}{l}\text { Northern analysis } \\
\text { Signal strength }\end{array}$} \\
\hline & & & & & NIL\#a & NIL\#b & NIL\#i & $\begin{array}{l}\text { Koshi- } \\
\text { hikari }\end{array}$ & NIL\#a & NIL\#b & NIL\#i \\
\hline $\begin{array}{l}97,378 \\
946,1068\end{array}$ & 1 & B1417F08 & Cysteine endopeptidase & - & $7.4^{\mathrm{c})}$ & $5.8^{\mathrm{c})}$ & $9.7^{\mathrm{c})}$ & + & +++ & +++ & +++ \\
\hline 1539 & 5 & P0554F08 & $\begin{array}{l}\text { Protease inhibitor/seed } \\
\text { storage/LTP family, putative }\end{array}$ & AK119689 & 5.8 & 7.0 & 6.4 & + & ++ & ++ & ++ \\
\hline 5350,4191 & 5 & P0016H04 & Metallothionein-like protein & AK058529 & $3.4^{\mathrm{c})}$ & $3.2^{\mathrm{c})}$ & $3.4^{\mathrm{c})}$ & + & ++ & ++ & ++ \\
\hline 8705 & 1 & $\mathrm{P} 0504 \mathrm{H} 10$ & Putative glycosyl hydrolase & AK110956 & 3.0 & 2.8 & 3.0 & + & ++ & ++ & ++ \\
\hline 8850,2214 & 9 & $\mathrm{P} 0515 \mathrm{~A} 04$ & Unknown & AK063844 & $4.3^{c)}$ & $3.7^{\mathrm{c})}$ & $3.0^{\mathrm{c})}$ & + & ++ & ++ & ++ \\
\hline $9005^{\text {d) }}$ & 1 & B1140D12 & SnoRNA & AK069030 & 3.8 & 2.4 & 2.5 & ++ & ++ & + & +++ \\
\hline 9026 & 1 & P0489A01 & Unknown & - & 3.5 & 2.5 & 2.4 & + & ++ & + & + \\
\hline 7113,7645 & 1 & B1015E06 & Metallothionein-like protein & AK120350 & $4.7^{\mathrm{c})}$ & $5.2^{\mathrm{c})}$ & $4.3^{c)}$ & & & & \\
\hline 1492 & 12 & OSJNBb0094E08 & Unknown & AK068646 & 3.3 & 3.7 & 4.2 & & & & \\
\hline 164 & 11 & OSJNBa0029D01 & $\begin{array}{l}\text { Nonphototropic hypocotyl } 1 \\
\text { (protein kinase) }\end{array}$ & AK065447 & 2.2 & 3.5 & 3.9 & & & & \\
\hline 8872 & 6 & P0416A11 & Putative cell-wall protein & AK103715 & 4.8 & 3.9 & 2.4 & & & & \\
\hline 619 & 2 & P0519E06 & Protein kinase & AK060657 & 3.7 & 2.5 & 3.7 & & & & \\
\hline 871 & 8 & P0013B04 & $\alpha$-Amylase & AK103413 & 2.3 & 3.8 & 3.0 & & & & \\
\hline 393 & 3 & OSJNBa0017N12 & $\begin{array}{l}\text { Putative phosphatidylserine } \\
\text { receptor long form }\end{array}$ & AK065339 & 2.9 & 2.2 & 3.2 & & & & \\
\hline 9046 & 4 & OSJNBb0108J11 & Unknown & AK102919 & 3.3 & 2.0 & 2.5 & & & & \\
\hline 120 & 5 & OSJNBa0017N18 & ADP glucose pyrophosphorylase & AK100910 & 2.5 & 2.0 & 3.0 & & & & \\
\hline 8956 & 3 & OSJNBa0004L11 & $\beta$-Glucosidase & AK103027 & 3.3 & 2.4 & - & & & & \\
\hline 3903 & 10 & OSJNBa0062C05 & $\begin{array}{l}\text { Putative senescence- } \\
\text { associated protein }\end{array}$ & AK103857 & - & - & 3.7 & & & & \\
\hline 749 & 6 & P0505A04 & $\begin{array}{l}\text { Transmembrane amino acid } \\
\text { transporter protein }\end{array}$ & AK073428 & - & - & 3.0 & & & & \\
\hline 4197 & - & - & Unknown & - & - & - & 2.9 & & & & \\
\hline $1723^{\text {e) }}$ & 8 & OJ1005_B05 & ACT domain, putative & - & 0.31 & 0.19 & 0.15 & + & + & ++ & ++ \\
\hline $7050^{\mathrm{e})}$ & 2 & $\mathrm{P} 0006 \mathrm{C} 08$ & Unknown & AK069678 & 0.33 & 0.35 & 0.35 & + & ++ & ++ & ++ \\
\hline
\end{tabular}

a): Fluorescence intensity ratios (each NIL/Koshihikari). Ratios between 0.50 and 2.0 are not shown.

b): B1417F08.21 was used as a substitute in cis-element search.

c): Average of induction ratio of 2 or 4 EST clones.

d): One EST clone, 9005 , was located in the region of $q S c 1-1$.

e): Two EST clones, 1723 and 7050, were repressed in microarray analysis, but their induction was clarified by Northern analysis. 
Table 2. List of 15 unique genes repressed in at least one NIL after subculture in medium containing 2,4-D

\begin{tabular}{|c|c|c|c|c|c|c|c|c|c|c|c|}
\hline \multirow[t]{2}{*}{$\begin{array}{l}\text { EST } \\
\text { clones }\end{array}$} & \multirow[t]{2}{*}{ Chr } & \multirow[t]{2}{*}{$\begin{array}{l}\text { PAC or } \\
\text { BAC clone }\end{array}$} & \multirow[t]{2}{*}{ Gene identification } & \multirow[t]{2}{*}{$\begin{array}{l}\text { Full-length } \\
\text { cDNA }\end{array}$} & \multicolumn{3}{|c|}{$\begin{array}{l}\text { Microarray analysis } \\
\text { Induced ratio }\end{array}$} & \multicolumn{4}{|c|}{$\begin{array}{l}\text { Northern analysis } \\
\text { Signal strength }\end{array}$} \\
\hline & & & & & NIL\#a & NIL\#b & NIL\#i & $\begin{array}{l}\text { Koshi- } \\
\text { hikari }\end{array}$ & NIL\#a & NIL\#b & NIL\#i \\
\hline 1341 & 3 & OSJNBa0023A13 & Unknown & b) & 0.26 & 0.18 & 0.25 & ++ & + & + & + \\
\hline 1614 & 4 & OSJNBb0049I21 & Unknown & AK103013 & 0.22 & 0.22 & 0.20 & ++ & + & + & + \\
\hline $2142^{\mathrm{c})}$ & 1 & P0440D10 & Jacalin-like lectin domain & AK062520 & 0.21 & - & 0.20 & ++ & + & + & ++ \\
\hline $2216,5948^{\mathrm{c})}$ & 1 & P0043B10 & Glutathione S-transferase & AK101436 & $0.30^{\mathrm{d})}$ & - d) & - d) & ++ & + & + & ++ \\
\hline 3477 & 4 & OSJNBa0004N05 & Caleosin-related protein, putative & AK063625 & 0.30 & - & 0.30 & ++ & + & + & ++ \\
\hline 6403 & 1 & P0688A04 & Cytochrome P450 & AK063764 & 0.26 & 0.30 & 0.27 & +++ & + & ++ & ++ \\
\hline 8432 & - & - & Unknown & - & 0.23 & 0.17 & 0.14 & +++ & +++ & ++ & ++ \\
\hline 439 & 4 & OSJNBb0060M15 & Unknown & - & 0.30 & 0.21 & 0.28 & & & & \\
\hline 2382 & 4 & OSJNBa0038O10 & $\alpha$-Amylase/subtilisin inhibitor & AK106723 & 0.38 & 0.43 & 0.31 & & & & \\
\hline 3389 & 5 & OJ1004E02 & VIP2 protein, putative & AK073521 & - & 0.47 & 0.32 & & & & \\
\hline 4860 & 1 & $\mathrm{P} 0485 \mathrm{~B} 12$ & $\begin{array}{l}\text { Protease inhibitor/seed storage/ } \\
\text { LTP family, putative }\end{array}$ & AK071598 & 0.19 & 0.26 & 0.40 & & & & \\
\hline 1916 & 9 & P0501E09 & Unknown & AK063582 & 0.22 & - & 0.22 & & & & \\
\hline 3660 & 8 & OJ1300_E01 & Ferredoxin I, chloroplast precursor & AK120393 & - & - & 0.34 & & & & \\
\hline 9016 & 6 & P0564B04 & ABC transporter-like protein & AK 105826 & 0.32 & - & - & & & & \\
\hline $2964^{\mathrm{e})}$ & 2 & OSJNBa0050G13 & Unknown & AK 121324 & 85.6 & 11.0 & 3.3 & ++ & ++ & + & ++ \\
\hline
\end{tabular}

a): Fluorescence intensity ratios (each NIL/Koshihikari). Ratios between 0.50 and 2.0 are not shown.

b): OSJNBa0023A13.4 was used as a substitute in cis-element search.

c): EST clones 2142, 2216, and 5948 were located in the region of qSc1-1.

d): Average induction ratio of 2 EST clones.

e): An EST clone, 2964, was induced in microarray analysis, but was found to be repressed in Northern analysis.

cade. Three genes were located in the region of the qSc11 (Fig. 1, Tables $1 \& 2$ ). It is not clear whether these genes were detected because of different transcript copy numbers or because of the different nucleotide sequences between Koshihikari and Kasalath.

Among the 22 induced genes (Table 1), six genes involved in seed germination were found, including cysteine endopeptidase $(97,378,946, \& 1068)$ and four genes contributing to starch metabolism: putative glycosyl hydrolase (8705), $\alpha$-amylase (871), ADP glucose pyrophosphorylase (120), and $\beta$-glucosidase (8956). Genes associated with seed storage proteins were also found: two members of a protease inhibitor/seed storage/ LTP family $(1539 ; 164)$, which might also be involved in the germination process. These results are consistent with the fact that calli of the NILs have more meristematic cells that proliferate well in comparison with Koshihikari callus.

Among the 15 repressed genes (Table 2), three genes were related to defense: Jacalin-like lectin (2142), glutathione S-transferase (2216 \& 5948), and cytochrome P450 (6403). This is consistent with the fact that the calli of the NILs are sounder than that of Koshihikari. Three genes, caleosin-related putative protein (3477), $\alpha$-amylase/subtilisin inhibitor (2382), and protease inhibitor/ LTP family (4860) were associated with seed storage pro- teins. VIP2 (3389) contained domains of the NOT2/ NOT3/NOT5 family; these domains form a nuclear complex that negatively regulates the basal and activated transcription of many genes (according to Pfam). This suggests that the NILs' calli cells were more activated in metabolism than those of the Koshihikari callus.

Ten genes had GA-response elements (GAREs), while ten had ABA-response elements (ABREs) (Table 3). Various GA-related cis-elements are known to act in concert with each other ${ }^{15}$. One of these is GARE as the main component, together with a pyrimidine box and an amylase element. Most genes having GARE also had other GA-related cis-elements in various combinations. This result implies that these GAREs are likely to act as cis-elements and that the genes are GA-responsive. The same goes for ABA-related cis-elements. Optimal ABA responsiveness usually requires the main component, ABRE, and other elements ${ }^{7}$. Ten genes had ABREs together with other ABA-related cis-elements, which implies these genes are likely to be ABA-responsive. In a microarray analysis in germinating Arabidopsis seeds, only $20 \%$ of promoters of GA-induced genes contained GARE-like sequences $^{14}$. This suggests that factors other than GARE may regulate these genes. Amylase elements are known to be involved in the regulation of sugar level ${ }^{8}$. A total of 17 genes had sequences of GARE and/or amy- 
F. S. Taguchi et al.

Table 3. Cis-element search in the 500-bp region upstream from the initiation codon of each mRNA or the 5' terminus of each full-length cDNA clone (A) Genes induced in NILs

\begin{tabular}{|c|c|c|c|c|c|c|c|c|c|c|c|c|}
\hline \multirow[t]{2}{*}{ EST clones } & \multirow[t]{2}{*}{ Gene identification } & \multicolumn{3}{|c|}{ GA } & \multicolumn{5}{|c|}{$\mathrm{ABA}$} & \multirow{2}{*}{$\frac{\text { Auxin }}{\mathrm{ARF}}$} & \multirow{2}{*}{$\frac{\text { Ethylene }}{\begin{array}{c}\text { AGC } \\
\text { box }\end{array}}$} & \multirow{2}{*}{$\frac{\text { Nitrogen }}{\begin{array}{l}\text { Endosperm Nial } \\
\text { motif }\end{array}}$} \\
\hline & & GARE & $\begin{array}{l}\text { E Pyrimidine } \\
\text { box }\end{array}$ & $\begin{array}{l}\text { Amylase } \\
\text { element }\end{array}$ & ABRE & DRE & $\begin{array}{c}\text { AT-rich } \\
\text { sequence }\end{array}$ & $\begin{array}{l}\mathrm{RY} \\
\text { repeat }\end{array}$ & MYC & & & \\
\hline $\begin{array}{l}97,378 \\
946,1068\end{array}$ & Cysteine endopeptidase & 4 & & & & & & & & & & \\
\hline 1539 & $\begin{array}{l}\text { Protease inhibitor/seed } \\
\text { storage/LTP family, putative }\end{array}$ & & 1 & & 1 & 1 & & 1 & 2 & & & \\
\hline 5350,4191 & Metallothionein-like protein & 1 & & 1 & 1 & & & & 1 & & & \\
\hline 8705 & Putative glycosyl hydrolase & & & & 2 & & & & & & & \\
\hline 8850,2214 & Unknown & 1 & 3 & 1 & & & & 1 & 2 & 1 & & \\
\hline 9005 & SnoRNA & 1 & 3 & & 1 & & & & & & 1 & \\
\hline 7113,7645 & Metallothionein-like protein & 3 & & & & & & & & & & \\
\hline 1492 & Unknown & & 1 & 1 & 1 & 2 & & 1 & & & 1 & \\
\hline 164 & $\begin{array}{l}\text { Nonphototropic hypocotyl } 1 \\
\text { (protein kinase) }\end{array}$ & & 2 & 1 & & & 1 & 1 & & & 1 & \\
\hline 8872 & Putative cell-wall protein & & 2 & & & & & 1 & 1 & & & \\
\hline 619 & Protein kinase & & 2 & & & & & & 1 & & 1 & \\
\hline 871 & $\alpha$-Amylase & & & 1 & & 1 & & & & & & \\
\hline 393 & $\begin{array}{l}\text { Putative phosphatidylserine } \\
\text { receptor long form }\end{array}$ & & 3 & & & & & & & & & \\
\hline 9046 & Unknown & & & & & & & 1 & 2 & & 1 & \\
\hline 120 & $\begin{array}{l}\text { ADP glucose pyrophospho- } \\
\text { rylase }\end{array}$ & & 2 & 1 & & & & & & & & \\
\hline 8956 & $\beta$-Glucosidase & & & & & 1 & 1 & 1 & 1 & & 1 & \\
\hline 3903 & $\begin{array}{l}\text { Putative senescence- } \\
\text { associated protein }\end{array}$ & & & & & 1 & & & & 1 & & \\
\hline 749 & $\begin{array}{l}\text { Transmembrane amino acid } \\
\text { transporter protein }\end{array}$ & & & & & & & & & & & \\
\hline 7050 & Unknown & & 3 & & 1 & & 1 & & 3 & & & \\
\hline
\end{tabular}

(B) Genes repressed in NILs

\begin{tabular}{|c|c|c|c|c|c|c|c|c|c|c|c|c|c|}
\hline \multirow{2}{*}{$\begin{array}{l}\text { EST } \\
\text { clones }\end{array}$} & \multirow[t]{2}{*}{ Gene identification } & \multicolumn{3}{|c|}{ GA } & \multicolumn{5}{|c|}{$\mathrm{ABA}$} & \multirow{2}{*}{$\frac{\text { Auxin }}{\text { ARF }}$} & \multirow{2}{*}{ 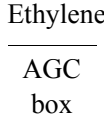 } & \multicolumn{2}{|l|}{ Nitrogen } \\
\hline & & GARE & $\begin{array}{l}\text { Pyrimidine } \\
\text { box }\end{array}$ & $\begin{array}{l}\text { Amylase } \\
\text { element }\end{array}$ & ABRE & DRE & $\begin{array}{l}\text { AT-rich } \\
\text { sequence }\end{array}$ & $\begin{array}{l}\mathrm{RY} \\
\text { repeat }\end{array}$ & MYC & & & $\begin{array}{l}\text { Endosperm I } \\
\text { motif }\end{array}$ & Nia1 \\
\hline 1341 & Unknown & & 1 & 1 & & & & & & & & & \\
\hline 1614 & Unknown & & & & & & & & & & & & \\
\hline 2142 & Jacalin-like lectin domain & 1 & 1 & 1 & 1 & & & 2 & 1 & & 1 & & \\
\hline 2216,5948 & Glutathione S-transferase & 1 & 4 & & & & & & & & & & \\
\hline 3477 & $\begin{array}{l}\text { Caleosin-related protein, } \\
\text { putative }\end{array}$ & & & & 3 & 1 & & 1 & 1 & 1 & & & \\
\hline 6403 & Cytochrome P450 & & 1 & & & & & & & & & & \\
\hline 2382 & $\alpha$-Amylase/subtilisin inhibitor & & & 1 & 1 & 1 & & & & & & & \\
\hline 3389 & VIP2 protein, putative & & 1 & & & & & & & 1 & 1 & & \\
\hline 4860 & $\begin{array}{l}\text { Protease inhibitor/seed } \\
\text { storage/LTP family, putative }\end{array}$ & $e^{1}$ & & & & & & & & & & & \\
\hline 1916 & Unknown & & 2 & 1 & & 2 & & & & & & 1 & \\
\hline 3660 & $\begin{array}{l}\text { Ferredoxin I, chloroplast } \\
\text { precursor }\end{array}$ & & 5 & & 1 & & & 1 & 2 & & & & \\
\hline 9016 & $\mathrm{ABC}$ transporter-like protein & 2 & 1 & & & & & & & 2 & & & 1 \\
\hline 2964 & Unknown & 1 & 3 & & & & & 1 & & 1 & & & \\
\hline
\end{tabular}

Sequence of cis-elements are as follows: GARE: TAAC(G/A)(A/T/G)A or CATGA(C/T)(G/A)TGG or CTACTC, pyrimidine box: (C/T)CTTTT or TTTTTTCC, amylase element: TATCCA(T/C) or TATCCA, ABRE: (T)ACGTG(G/T)C or ACGTSSSC (S = C/G), DRE: (G/A)CCGAC, AT-rich: CAAT(C/G)ATTG or CAATTATTA, RY repeat: CATGCA, MYC: CA(TG/CA)TG, ARF: TGTCTC, AGC box: AGCCGCC. 
lase elements (Table 3), which indicates that more than half of the screened genes may be involved in germination.

Overall, NILs covering QTLs associated with callus proliferation were applied to a microarray analysis for the first time, and the results of the microarray analysis implied that the expression profiles of germinationrelated genes differed between each NIL and Koshihikari. More accurate microarray analysis using isogenic lines is needed to clarify characterization of the QTLs.

\section{References}

1. Akimoto-Tomiyama, C. et al. (2003) Rice gene expression in response to $\mathrm{N}$-acetylchitooligosaccharide elicitor: comprehensive analysis by DNA microarray with randomly selected ESTs. Plant Mol. Biol., 52, 537-551.

2. Armstrong, C. L., Romero-Severson, J. \& Hodges, T. K. (1992) Improved tissue culture response of an elite maize inbred through backcross breeding, and identification of chromosomal regions important for regeneration by RFLP analysis. Theor. Appl. Genet., 84, 755-762.

3. Chugh, A. \& Khurana, P. (2002) Gene expression during somatic embryogenesis-recent advances. Curr. Sci., 83, 715-730.

4. Daigen, M., Kawakami, O. \& Nagasawa, Y. (2000) Efficient anther culture method of the Japonica rice cultivar Koshihikari. Breed. Sci., 50, 197-202.

5. Hashizume, F. et al. (1999) Efficient Agrobacteriummediated transformation and the usefulness of a synthetic GFP reporter gene in leading varieties of Japonica rice. Plant Biotech., 16, 397-401.

6. Higo, K. et al. (1998) PLACE: a database of plant cis-acting regulatory DNA elements. Nucl. Acids Res., 26, 358359.

7. Himmelbach, A., Yang, Y. \& Grill, E. (2003) Relay and control of abscisic acid signaling. Curr. Opin. Plant
Biol., 6, 470-479.

8. Hwang, Y. -S. et al. (1998) Three cis-elements required for rice $\alpha$-amylase Amy3D expression during sugar starvation. Plant Mol. Biol., 36, 331-341.

9. Kikuchi, S. et al. (2003) Collection, mapping, and annotation of over $28,000 \mathrm{cDNA}$ clones from japonica rice. Science, 301, 376-379.

10. Nishimura, A. et al. (2005) Isolation of a rice regeneration quantitative trait loci gene and its application to transformation systems. Proc. Natl. Acad. Sci. USA, 102, 11940-11944.

11. Mano, Y. et al. (1996) Mapping genes for callus growth and shoot regeneration in barley. Breed. Sci., 46, 137142.

12. Mano, Y. \& Komatsuda, T. (2002) Identification of QTLs controlling tissue-culture traits in barley (Hordeum vulgare L.). Theor. Appl. Genet., 105, 708-715.

13. Ogawa, T. et al. (1999) Relationships between nitrite reductase activity and genotype-dependent callus growth in rice cell cultures. Plant Cell Rep., 18, 576-581.

14. Ogawa, M. et al. (2003) Gibberellin biosynthesis and response during Arabidopsis seed germination. Plant Cell, 15, 1591-1604.

15. Sun, T. \& Gubler, F. (2004) Molecular mechanism of gibberellin signaling in plants. Annu. Rev. Plant Biol., 55, 197-223.

16. Taguchi-Shiobara, F. et al. (2006) Mapping QTLs that control the performance of rice tissue culture and evaluation of derived near-isogenic lines. Theor. Appl. Genet., 112, 968-976.

17. Yamamoto, T. et al. (2001) Mapping quantitative trait loci for days-to-heading, and culm, panicle and internode lengths in $\mathrm{BC}_{1} \mathrm{~F}_{3}$ population using an elite rice variety, Koshihikari, as the recurrent parent. Breed. Sci., 51, 6371.

18. Yazaki, J. et al. (2000) Embarking on rice functional genomics via a cDNA microarray with 1265 genes: use of 3'UTR probes for specific gene expression analysis. DNA Res., 7, 367-370. 